\title{
Community Communication Network in Preserving Culture: A Case Study in Betawi Setu Babakan Cultural Village
}

\author{
Sri Hartati ${ }^{1 *}$, Damayanti Masduki ${ }^{2}$, Riyana Putri Nurkhalisa ${ }^{3}$ and Edwin Karim ${ }^{4}$ \\ ${ }^{I}$ School of Business and Management,Institut Teknologi Bandung,Indonesia \\ ${ }^{2}$ Faculty of Communication Science, UPN Veteran Jakarta, Indonesia \\ ${ }^{3}$ Faculty of Communication Science, UPN Veteran Jakarta, Indonesia \\ ${ }^{4}$ Faculty of Management,STIE Gema Widya Bangsa Bandung,Indonesia \\ *Correspondence author email: sri.hartati@sbm-itb.ac.id
}

\begin{abstract}
The purpose of this study was to determine the relationship of the Betawi community communication network through two stages of analysis, namely describing the flow of the community communication network and explaining the relationship of the Betawi community communication network. The method used in this research is through direct observation of the culture of the Betawi people, namely Betawi art performances, document studies in online media and in-depth interviews with selected actors to become resource persons based on successive recommendations from key informants. The results showed that there are 5 elements in the structure of the Betawi community communication network in preserving culture, namely: components, clicks, bridges, hubs, and cutpoints and there are 2 streams of communication networks that connect between actors in preserving Betawi culture, namely Path and Walk. This communication network plays a very important role in providing information in preserving the culture of the Betawi people. The communication network structure of the Betawi community in the Betawi Cultural Village has a synergistic relationship with the Government, cultural actors and the community. The function of each link that is formed in general is to maintain and develop Betawi culture so that Betawi culture will continue into the future.
\end{abstract}

Keywords: Community Communication Network, Betawi Setu Babakan, Cultural Village

\section{INTRODUCTION}

Indonesia is a country rich in cultural heritage. Indonesia has 7,241 legacies from 34 provinces which are the pride of the Indonesian people. Cultural heritage is a whole cultural heritage that has historical importance, science and technology, and art [1].Cultural heritage possesses are of various kinds, from traditional clothing, traditional arts, distinctive architecture to customary rules that are still inherent in several regions in Indonesia. Culture plays an important role in the progress of a nation. Along with the development of information technology today, technology does not only affect human life in the field of communication or economics, but also on culture which is the nation's treasure. In the current era of globalization, it is very easy for foreign cultures to enter so that regional cultures are increasingly marginalized in the way of life of society. People are more receptive to foreign cultures. This can occur due to a variety of factors. One of them is the role of the government in preserving this culture.
Today the challenges and opportunities that come from a traditional Indonesian cultural heritage, the Government has begun to be serious and has begun to be active in the development of Indonesian cultural tourism destinations, one of which is the flagship destination of SetuBabakanBetawi Village which is owned by the Provincial Government of DKI Jakarta. The Betawi Cultural Village SetuBabakan is currently more functioned as cultural tourism accommodated by the Regional Government with the aim of saving cultural assets for the Betawi ethnicity itself. In every policy that islowered the government cannot be separated fromthe existence of a political, economic, social, culture and also tourism, rememberingSetuBetawi cultural villagebabakan is a cultural assetpotential enough for the government andBetawi continuity going forward.The role of social agencies shows that the influence of the Betawi elite plays a role as supervisor of policy and development of the area. The management of the BetawiSetuBabakan Village is carried out in collaboration with the surrounding community and groups of Betawi cultural artists to 
interact continuously in order to maintain and socialize to the people of Jakarta in particular to participate in appreciating and preserving traditional Betawi culture, so that if you pay attention there will be patterns the communication network formed as a result of the long communication process by the manager of the Betawi Village SetuBabakan with other individuals or groups.

\section{LITERATURE REVIEW \\ 2.1.Communication}

Communication is a tool that humans have to regulate, stabilize and modify their social life. Social processes depend on the accumulation, exchange and transmission of knowledge. In turn, knowledge depends on communication. According toLasswellin that the right way to explain an act of communication is to answer the question of who delivered, what was conveyed, through what channels, to whom and what effect. Steven in said that communication occurs whenever an organism reacts to an object or stimuli. Does it come from someone or the surrounding environment. Claude E. Shannon and Warren Weafer in two electrical engineers stated that "the occurrence of the communication process requires five elements that support it, namely sender, transmitter, signal, receiver, and destination. If these elements are described, the relationship between one element and another is the source, message, media, message recipient, influence, feedback and the environment. Each element has a very important role in building the communication process, even these seven elements depend on each other, meaning that without the participation of one element will have an influence on the course of communication.

In Indonesia, the development of internet use to date is 176.71 million people out of a total population of 266.91 million Indonesians. One of the reasons for the increase in internet use is the use of smartphones as media that can access the internet. Media is an intermediary for a communication process such as when a person writes a letter, then the media used is paper or when calling using the telephone media while according to, social media is a media platform that focuses on the existence of users who facilitate them in activities and collaborating. Therefore, social media can be seen as an online medium (facilitator) that strengthens the relationship between users as well as a social bond. Social media is a collection of software that allows individuals and communities to gather, share, communicate, and in certain cases collaborate or play with each other. Social media has the power of user-generated content (UGC) where the content is generated by users, not by editors like in mass media institutions. Social media refers to "content distributed through social interactions [2] .

\subsection{Communication network analysis}

Human daily life cannot be separated from communication activities. In general, this communication activity is carried out to meet various needs of life, either by verbal or nonverbal communication. Humans tend to communicate in the family environment, school, work environment or places that have public facilities. In short, humans will communicate anywhere and anytime to meet personal or group needs. From this communication process, patterns that connect between individuals will be formed. Networks are relational systems in which actors, e.g., persons or organizations, are embedded the focus can be on the structure of networks, but also on connections as a resource. According to Sendjaja in, technological advances make one person connect with another. This is supported by the presence of several social media which allows each individual to connect with other people. Of course, these connections are not limited by time and space, everyone has the ability to communicate with anyone, anywhere with any social media. Network as a set of relationships between social actors. Eriyanto concluded that from this definition there are two important parts of network analysis, namely actors and relationships between actors. Actors can be individuals or groups, while a link is a relationship between actors. The network also has a flow (flow) that connects all actors in the network. Communication network is the exchange of messages between a number of people who occupy a certain position or role. A communication network is different in size and structure, for example, maybe only between two or three people, or maybe more and maybe also among all people in the organization. Meanwhile, the communication network according is a network consisting of interconnected individuals connected by a patterned flow of communication [3].

In connection with the formation of communication networks, the term network in the context of communication refers to a grouping of a number of individuals or others who interact with each other according to certain relationship patterns from time to time in essence, a communication network is a relationship- homophile relationships, namely the tendency of humans to have relationships with people who have the same attributes as themselves. However, it does not mean that a communication network can only occur to people who have the same attributes, because the communication relationship that occurs in the network will affect the mindset and behavior of the people involved. Furthermore, that communication networks produce various types of data regarding the characteristics and structure of a network. Communication networks can be divided into 2 categories. First, differences based on study design 
(network structure as a whole or focus on actors). Second, the level of analysis (individual actors or groups, or the network as a whole) [4].

\section{RESEARCH METHODS}

The method used a case study. According to [5], the case study method has advantages and is more suiTABLE for research that answers the 'how' or 'why' questions that will be directed to a series of contemporary events, where the research has very little or no chance of exercise control over these events ".Communication network research uses descriptive type where the research is intended to describe in detail the structure of the community communication network. The data obtained are primary data and secondary data. Data analysis techniques using network analysis. Network analysis allows researchers to search for the flow of messages formed in the Betawi Cultural Village in order to preserve Betawi culture. The data validity technique uses the triangulation technique with the source method, then compares the results of interviews between the main informant and other informants or compares the results of document studies and visits to the Betawi Cultural Village Setu Babakan.

\section{RESULT AND DISCUSSION 4.1.Communication network structure}

The Betawi community uses two ways of communicating, namely by using the media, and face to face directly. The chairperson or related division does not need to come one by one group members to give invitations, with the facilities that are always up to date, the invitation letter is sufficiently photographed with good image quality to then be distributed in an institutional group where group members are participants included in the invitation. This direct face-to-face communication is still often carried out by the Betawi community in an effort to encourage the preservation of Betawi culture.

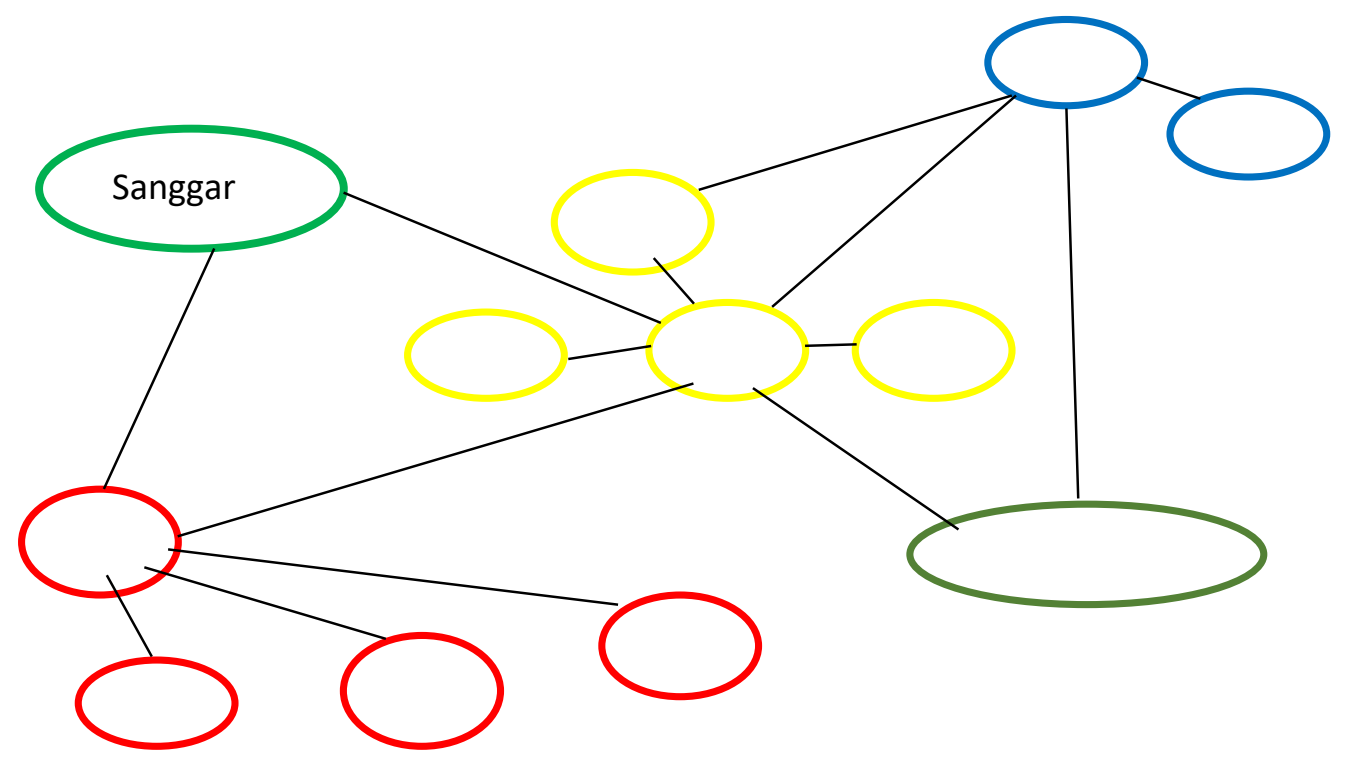

FIGURE 1. Structure of the Betawi Community Communication Network in Setu Babakan Betawi Village

The elements in the BetawiSetuBabakan community communication network namely:

a. Componentsis a grouping of actors who have at least one link in the network. They are called:
1(SA), A2(II),A3(PB),A4(M),B1(IS),B2(YAS), C1(SA),C2(IH),C3(AN),C4(YAS)and C5(YM)

b. Clicks are formed from the communication pattern. FIGURE 1 is 3 clicks. First click A1-A2B1, second click A1-B1-Society, and third click A1-C3-Sanggar.

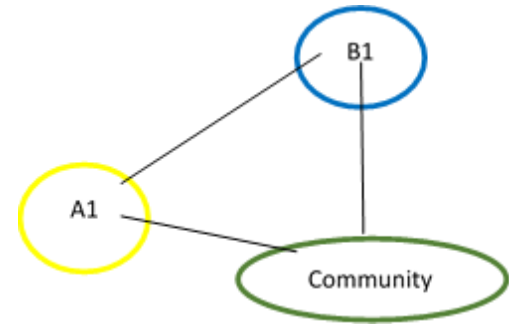

FIGURE 2. First click and second click

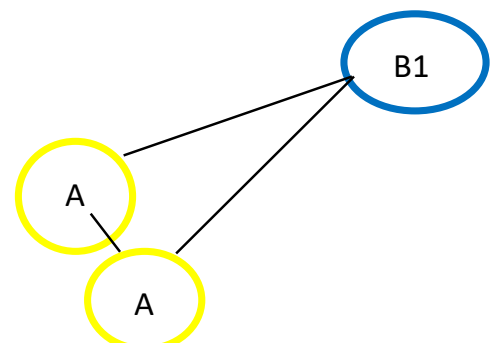


c. Bridgesare links that connect two separate groups in a network. Links C3-A1 and A2-B1, and A1-B1.(FIGURE 3.)
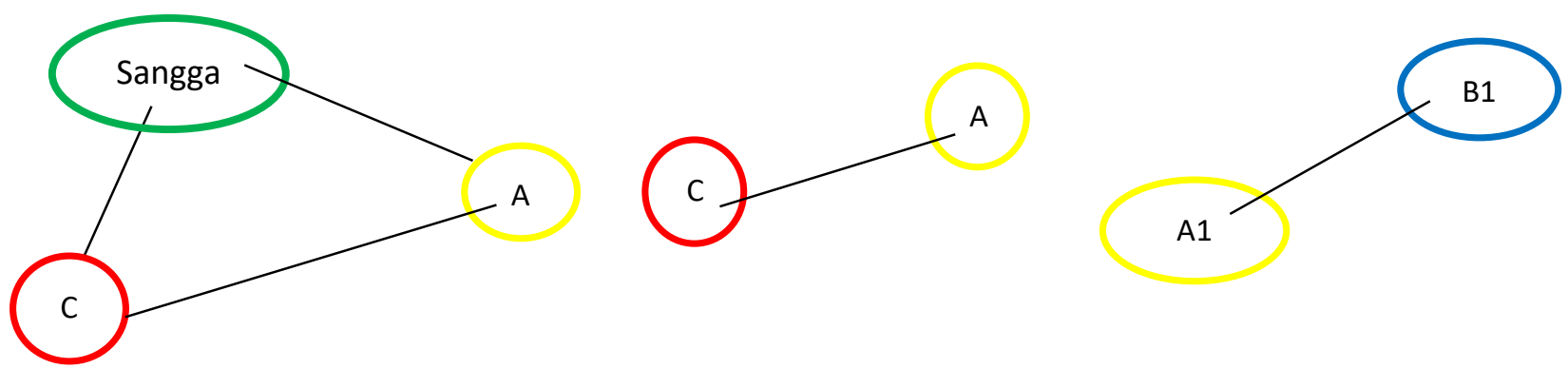

FIGURE 3. Third click and Briges

d. Hubs are the most connected actors in the network. The actor with the most connections is actor A1 who has 7 links (FIGURE 4.)

e. Cutpoints, cutpoints are actors that become the glue in the network, where without the actor's presence, the network will separate. The cutpoints in the picture are shown by actors A, B, and $\mathrm{C}$. The types of relations that exist in the communication network pattern according to FIGURE 5 are:

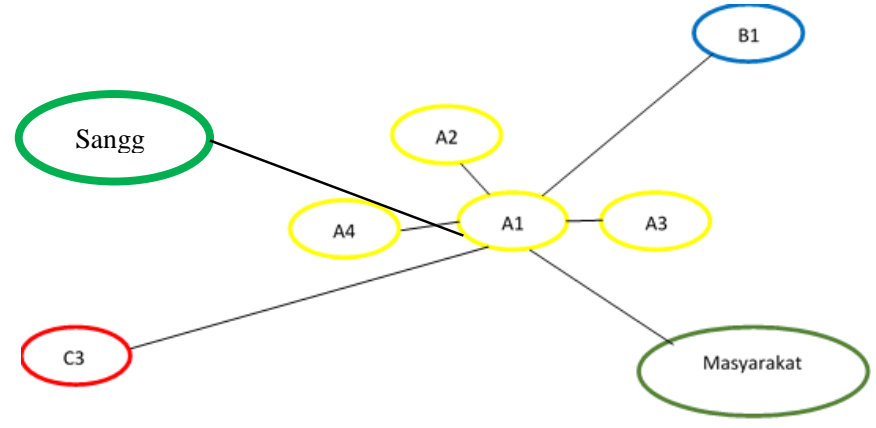

FIGURE 4. Hubs

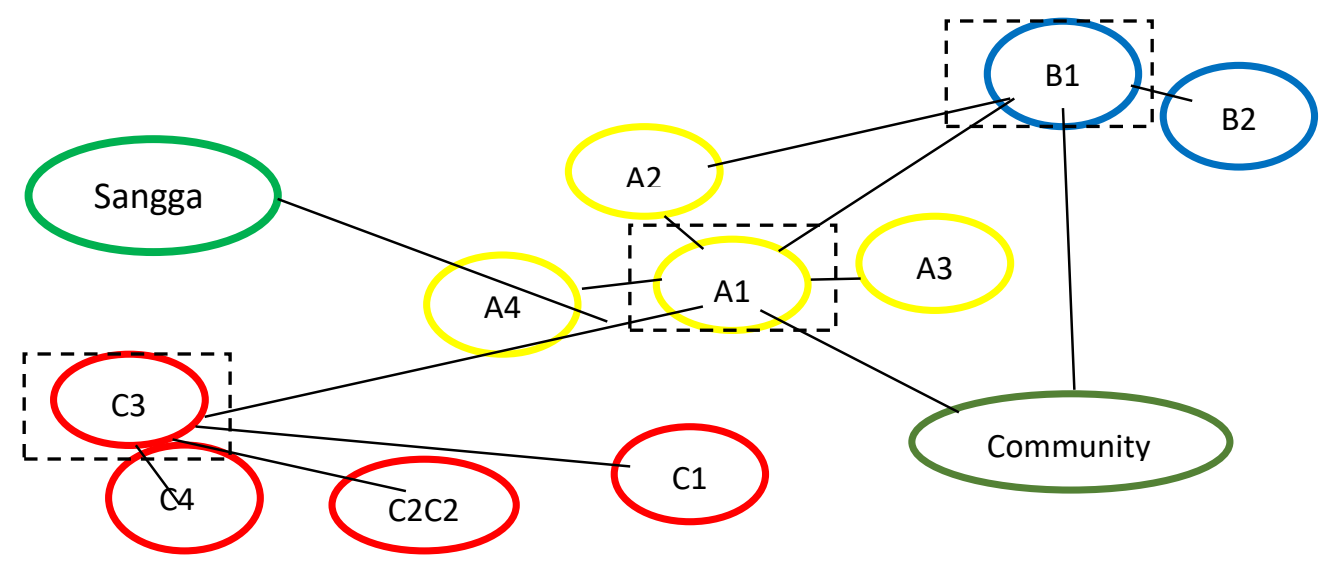

FIGURE 5. Cutpoints

\section{CONCLUSION}

The communication network structure of the Betawi community in the Betawi Cultural Village has a synergistic relationship with the Government, cultural actors and the community. The function of each link that is formed in general is to maintain and develop Betawi culture so that Betawi culture will continue into the future. Relations in a network also 
play an important role, one of which is to develop existing communication flows. The biggest challenge in preserving Betawi culture is the onslaught of influences from the increasingly open times. Therefore, to overcome the onslaught of outside influences, all parties must have an awareness of the importance of Indonesian cultural heritage and jointly participate actively in preserving traditional culture, especially Betawi culture both as actors and participants who provide support for the preservation of Betawi culture.

\section{REFERENCES}

[1] Kemetrian pendidikan dan Kebudayaan, Analisis Partisipasi Kebudayaan. Jakarta, 2018.

[2] H. Cangara, Pengantar Ilmu Komunikasi. Depok: PT Raja Grafindo Persada, 2012.
[3] J. Van Djick, The Culture of Connectivity: A Critical History of Social Media. Oxford, UK: Oxford University Press, 2013.

[4] R. Gustina, Hubeis, "Jaringan Komunikasi Dan Peran Perempuan Dalam Mempertahankan Budaya Rudat (Studi Pada Masyarakat Desa Negeri Katon, Kecamatan Negeri Katon, Lampung Selatan)," J. Komun. Pembang., vol. 6, no. 1, 2008.

[5] Saleh Md. Arman, "Integrated model of Social Media and Customer Relationship Management: A Literature Review," Int. J. Information, Bus. Manag., vol. 6, no. 3, 2014. 